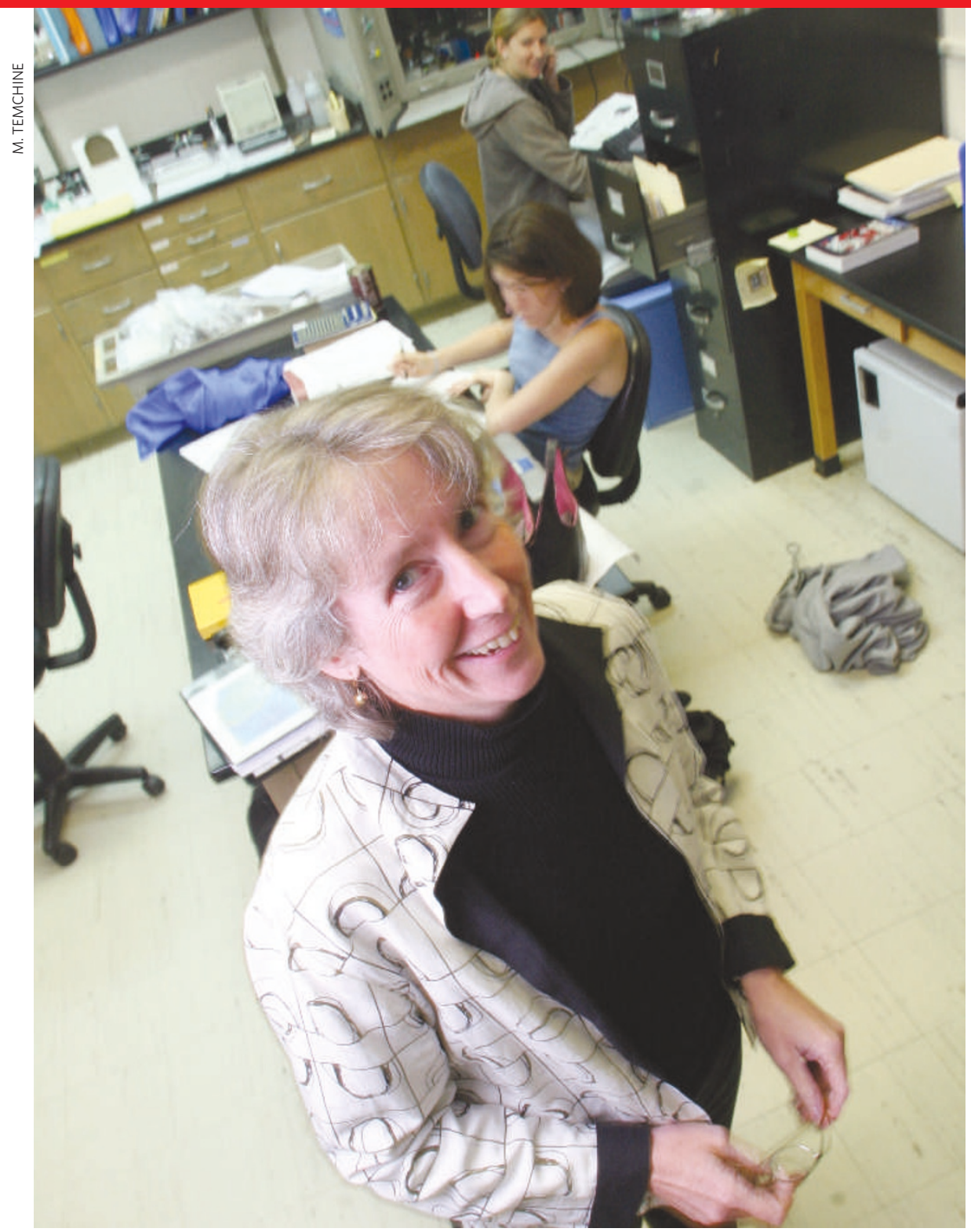

\title{
The life aquatic
}

Cindy Lee Van Dover likes nothing better than to be on the ocean floor. Emma Marris meets the unconventional biologist who has
devoted her life to studying the exotic ecosystems of the deep.

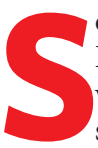

ome 2,300 metres under the sea, Richard Lutz was beginning to wonder whether he should worry. The deep-sea submersible Alvin in which he was riding had come to a shuddering halt. Next to him, the pilot stared intently out of the windows.

"We can't move," said Cindy Lee Van Dover, at the controls of a truck-sized craft stuck at the bottom of the ocean. "We are just going to sit here and think."

As Lutz, a marine biologist at Rutgers University, tells it, Van Dover's calm approach got them out of a potentially deadly situation that day in 1991. He was readying his handheld tape recorder to capture his last words, but after checking and rechecking Alvin's controls,
Van Dover concluded that the sub's front shield had probably scooped up hundreds of kilograms of mud. Hours later, she had managed to ditch enough weight to allow the sub to ascend safely to the surface.

Such deliberate cool in the face of danger is practically a requirement for deep-sea pilots. But it has served Van Dover equally well in her unconventional academic career studying deep-sea ecosystems. In a small field crowded with powerful personalities, she has sometimes irritated the establishment by not following a traditional path. Yet her trademark intensity - a quality she readily describes as "stubbornness" - has often helped her to ride out the storms.
Van Dover has racked up hundreds of hours in submersibles on the sea floor, including a period in the early 1990s when she spent more time on the ocean bottom than any other scientist. That experience, combined with her natural curiosity for all things oceanic, set the stage for her to make leaps of reasoning that might seem counterintuitive to her colleagues, but which sometimes result in startling new insights into vent creatures.

These creatures thrive in a peculiar environment that, at first glance, seems hostile to life. They live along cracks in the sea floor where water, superheated by volcanic activity, gushes out of towering chimneys. These hydrothermal vents are home to communities of fantastic organisms ranging from mats of bacteria living off sulphides to long, pale, red-tipped tubeworms that sway in the current.

\section{All at sea}

An invertebrate zoologist at heart, Van Dover finds this diversity inspiring. She is excited by, as she puts it, "all the weird ways you can be alive". Her explorations have taken her from the relatively well characterized vents on the mid-Atlantic ridge, to the rarely visited depths of the Indian Ocean and the seas around Fiji and Easter Island.

Yet despite all the time she has spent on and in - the water, Van Dover still gets seasick on the first few days of a voyage. Not that she lets that put her off. "I love the romance of going to sea," she says with a smile."I love the phrase, 'I'm going to sea."

This life-long passion arose when she was an undergraduate studying zoology at Rutgers. Fascinated by the bizarre biology of deep-sea creatures, she applied to the joint graduate programme in oceanography run by the Massachusetts Institute of Technology and the Woods Hole Oceanographic Institution (WHOI). When she didn't get in, she spent six years working as an itinerant lab technician and sharpening her mathematical skills until she was accepted on to the programme.

At the WHOI, Van Dover was soon making waves with a seemingly outlandish hypothesis: she believed that there may be a light source in the inky depths by the vents. Van Dover had been puzzling over a species of eyeless rift shrimp called Rimicaris exoculata, which had been recovered from the Atlantic. Watching videos of the shrimps at the vents, she saw two reflective patches running down their backs. But when she examined the specimens brought to the surface, she found that the preservation process had rendered the blotches invisible.

The patches, which had never been noticed before, looked like some kind of sensor. Van Dover guessed that they might be highly modified eyes for sensing light. But why would a shrimp in the lightless depths need eyes?

To find out if there was any light to respond to, Van Dover asked researchers going on a ventmapping expedition to use a sensitive camera, designed for astronomical imaging, to take pic- 
